\title{
Callus induction of leaf expalnts of Talinum paniculatum
}

\author{
Prianangkai Karuppiah; Weng Hing Thong
}

\begin{abstract}
Talinum paniculatum is an edible plant with enormous medicinal properties. The main focus of this study was on callus induction due to the natural ability of callus that can regenerate into a new plant. This study was carried out to determine the effects of 2,4-Dichlorophenoxyacetic Acid (2,4-D) and 6-benzylaminopurine (BAP) on callus induction of $T$. paniculatum from leaf explant. Leaf explants of $T$. paniculatum were cultured on Murashige \& Skoog (MS) media containing 2,4-D at concentrations of 1.0, 2.0, 3.0, 4.0 and $5.0 \mathrm{mg} / \mathrm{L}$ and BAP at concentrations of $0.5,1.0,1.5,2.0$ and $2.5 \mathrm{mg} / \mathrm{L}$ under single exposure or combined exposure. Explants cultured on medium containing no plant growth regulators (PGR) served as control in this experiment. The effectiveness of PGRs on callus induction of $T$. paniculatum was determined by recording the callus induction day, percentage of callus induced in all the treatments and morphology of the callus induced. Leaf explants treated with 2,4-D and BAP in combined exposure resulted in callus induction. Highest percentage of callus from leaf explants was produced on the medium containing $2.0 \mathrm{mg} / \mathrm{L}$ of $2,4-\mathrm{D}$ and $2.5 \mathrm{mg} / \mathrm{L}$ of $\mathrm{BAP}$ in combined exposure. In conclusion, callus induction of $T$. paniculatum could serve as an alternative regeneration pathway for this important medicinal pant.
\end{abstract}

Keywords—callus, plant growth regulators, BAP, 2,4-D

\section{Introduction}

In general, callus is known as an unorganized growing mass of cells in response to stress which includes wounding of cells. Explants cultured on media suitable for formation of undifferentiated cell leads to development of callus. Callus production of most cells is aided by auxin and cytokinin [1]. In normal plant development the unorganized cell proliferation is suppressed but environmental and genetic impact overcome it to induce callus formation [2].

Callus induction requires equal concentration of cytokinin and auxin. High concentration of cytokinin from auxin would result in formation of shoots whereas high ratio

\section{Prianangkai Karuppiah}

INTI International University

Malaysia

Weng Hing Thong

INTI International University

Malaysia of auxin to cytokinin would induce the formation of root [3]. Callus induction process is more responsive in dicotyledonous plants when compared to monocotyledons. Meanwhile, woody plants seem to have even slower rate of callus induction [4]. Callus induction can be categorized according to their morphological structure which includes compact, friable and mucilaginous callus [5]. Commonly, friable callus is the most desired ones to be used compared to the two other types of callus [6].

T. paniculatum originates from the Portulacaceae family. The Portulacaceae family consist of 20 genera and 500 species. The Talinum genus comprises of 23 species [7]. T. paniculatum with a well-developed root system can grow up to $30 \mathrm{~cm}$ height [8]. It grows naturally all around the world and is widespread in North Africa, South America and East Asia especially in China. It is normally kept as a decorative plant in gardens and farms. It is also a medicinal plant that is used in the treatment of type- 2 diabetes, headaches, pneumonia, diarrhea, gastrointestinal problems, common weakness and reproductive disorders [8]. Moreover, it also has the anti-inflammatory properties that aids in the treatment of inflammatory processes [8]. T. paniculatum also known as Jewls of opar, has stems that are seldom branched and if it is branched, the branches would be very few and distributed at the base. The leaves of the plants are arranged alternately, whereby it is attached directly to the base but not to the stalks [9]. The dark pink bowl shaped flowers of the plant are found on the lacy stalks of the plant [7]. The flowers are small and they carry red buds and globular shaped fruits that happen to be bees' favorite [10].

To date, there is few preservative action done to protect this plant form the rapid development of wild land. Hence before it reaches the stage of extinction, a precautionary step can be taken via implementing the callus induction to increase the population of this medicinal plant. This step would avoid the plant from facing extinction overtime. Besides that, this medicinal plant may contain valuable compounds that haven't been identified yet. Hence callusing would allow further research on this plant and identification of those valuable compounds that can later on be used in industries such as pharmaceutical or cosmetics. In addition, research on callus induction will also allow genetic modification of the plant in future. Therefore, the aim this study was to determine the optimum concentration of 2,4dichlorophenoxyacetic acid (2,4-D) and 6benzylaminopurine (BAP) in single or combined exposure on callus induction of $T$. paniculatum from leaf explants. 


\section{Materials and Methods}

\section{A. Plant Material}

The seeds of $T$. paniculatum which served as the source of explant were collected from Desa Casuarina, Nilai, Negeri Sembilan, Malaysia.

\section{B. Establishment of aseptic culture}

The seeds of $T$. paniculatum were sterilized using $75 \%$ ethanol for a duration of one minute followed by rinsing three times with sterile deionized water. They were then sterilized using sodium hypochlorite $(\mathrm{NaOCl})$ and Triton $\mathrm{X}$ 100 as detergent for 10 minutes. After this step, the seeds were rinsed with sterile deionized water for three times before culturing them onto MS medium. Daily observation was done to obtain the percentage of aseptic and survival of culture for two weeks.

\section{Effects of various concentrations of 2,4-D and BAP on callus induction}

Leaf segments $(5 \mathrm{~mm} \times 5 \mathrm{~mm})$ of $T$. paniculatum were used as the explants in this experiment. The excised leaf explants were placed on Murashige and Skoog (MS) [11] medium which contains different concentrations of 2,4-D $(1.0,2.0,3.0,4.0$ and $5.0 \mathrm{mg} / \mathrm{L})$ and $\operatorname{BAP}(0.5,1.0,1.5,2.0$ and $2.5 \mathrm{mg} / \mathrm{L}$ ) via single and combined exposure. The control medium was prepared without any supplementation of PGR. Five explants were cultured in a Petri dish. 3 replicates for each treatment were prepared. The Petri dishes were then covered with its lids and sealed tightly with parafilm. The Petri dishes with the leaf explants were incubated in growth chamber at $25 \pm 2 \mathrm{C}$ in total darkness. Daily observation of the cultures was done to identify the callus induction day. The concentration at which the callus was being induced, as well as the percentage of callus formed was also observed and recorded for a duration of eight weeks.

\section{Results}

\section{A. Establishment of aseptic culture}

The seeds of $T$. paniculatum were aseptically cultured on MS medium. All the seeds cultured were observed to have germinated. Hence the germination rate of the seeds was $100 \%$. It took two complete weeks for the seeds to start germinating. Moreover, the seed culture also achieved 100\% sterility.

\section{B. Effects of various concentrations of 2,4-D and BAP on callus induction}

In this study, there was no callus induced in the plates containing MS medium devoid of 2,4-D and BAP but presence of roots and shoots were observed. Referring to Table 1 , it was noticed that no callus was observed in plates containing $1.0 \mathrm{mg} / \mathrm{L}, 2.0 \mathrm{mg} / \mathrm{L}, 3.0 \mathrm{mg} / \mathrm{L}, 4.0 \mathrm{mg} / \mathrm{L}$ and 5.0 $\mathrm{mg} / \mathrm{L}$ of $2,4-\mathrm{D}$. Same goes to medium containing $0.5 \mathrm{mg} / \mathrm{L}$, $1.0 \mathrm{mg} / \mathrm{L} 1.5 \mathrm{mg} / \mathrm{L} 2.0 \mathrm{mg} / \mathrm{L}$ and $2.5 \mathrm{mg} / \mathrm{L}$ of B AP, no callus was observed.

TABLE 1. EFFECT OF DIFFERENT CONCENTRATIONS OF 2,4-D AND BAP ON CALLUS FORMATION OF T. paniculatum FROM LEAF EXPLANTS OVER A PERIOD OF EIGHT WEEKS

\begin{tabular}{|c|c|c|}
\hline \multicolumn{2}{|c|}{ Media Combination } & \multirow{2}{*}{$\begin{array}{c}\text { Percentage } \\
\text { of callus } \\
\text { induction }\end{array}$} \\
\hline $\begin{array}{l}\text { 2,4-D } \\
\text { (mg/L) }\end{array}$ & $\begin{array}{c}\text { BAP } \\
(\mathrm{mg} / \mathrm{L})\end{array}$ & \\
\hline 0 & 0 & 0 \\
\hline 1.0 & 0 & 0 \\
\hline 2.0 & 0 & 0 \\
\hline 3.0 & 0 & 0 \\
\hline 4.0 & 0 & 0 \\
\hline 5.0 & 0 & 0 \\
\hline 0 & 0.5 & 0 \\
\hline 0 & 1.0 & 0 \\
\hline 0 & 1.5 & 0 \\
\hline 0 & 2.0 & 0 \\
\hline 0 & 2.5 & 0 \\
\hline 1.0 & 0.5 & 90 \\
\hline 2.0 & 0.5 & 90 \\
\hline 3.0 & 0.5 & 70 \\
\hline 4.0 & 0.5 & 50 \\
\hline 5.0 & 0.5 & 20 \\
\hline 1.0 & 1.0 & 70 \\
\hline 2.0 & 1.0 & 70 \\
\hline 3.0 & 1.0 & 60 \\
\hline 4.0 & 1.0 & 40 \\
\hline 5.0 & 1.0 & 20 \\
\hline 1.0 & 1.5 & 90 \\
\hline 2.0 & 1.5 & 90 \\
\hline 3.0 & 1.5 & 60 \\
\hline 4.0 & 1.5 & 60 \\
\hline 5.0 & 1.5 & 5 \\
\hline 1.0 & 2.0 & 75 \\
\hline 2.0 & 2.0 & 65 \\
\hline 3.0 & 2.0 & 50 \\
\hline 4.0 & 2.0 & 30 \\
\hline 5.0 & 2.0 & 5 \\
\hline 1.0 & 2.5 & 90 \\
\hline 2.0 & 2.5 & 100 \\
\hline 3.0 & 2.5 & 40 \\
\hline 4.0 & 2.5 & 20 \\
\hline 5.0 & 2.5 & 15 \\
\hline
\end{tabular}

Callus induction from leaf explants treated with combined exposure of both 2,4-D and BAP was achieved on day six. Based on Table 1, medium containing $2.0 \mathrm{mg} / \mathrm{L}$ of 2,4-D and $2.5 \mathrm{mg} / \mathrm{L}$ of BAP induced the highest percentage of callus formation which was $100 \%$. This was followed by $90 \%$ percentage callus induction in combined treatment of $1.0 \mathrm{mg} / \mathrm{L}$ of $2,4-\mathrm{D}$ and $1.5 \mathrm{mg} / \mathrm{L}$ of BAP, $1.0 \mathrm{mg} / \mathrm{L}$ of $2,4-\mathrm{D}$ and $2.5 \mathrm{mg} / \mathrm{L}$ of BAP, $2.0 \mathrm{mg} / \mathrm{L}$ of $2,4-\mathrm{D}$ and $1.5 \mathrm{mg} / \mathrm{L}$ BAP, $1.0 \mathrm{mg} / \mathrm{L}$ of $2,4-\mathrm{D}$ and $0.5 \mathrm{mg} / \mathrm{L}$ of $\mathrm{BAP}$, and 2.0 $\mathrm{mg} / \mathrm{L}$ of $2,4-\mathrm{D}$ and $0.5 \mathrm{mg} / \mathrm{L} \mathrm{BAP}$.

The callus induced under the combined exposure of $1.0 \mathrm{mg} / \mathrm{L}$ of $2,4-\mathrm{D}$ and $2.5 \mathrm{mg} / \mathrm{L}$ of $\mathrm{BAP}$, and $2.0 \mathrm{mg} / \mathrm{L}$ of 2,4-D and $0.5 \mathrm{mg} / \mathrm{L}$ of BAP was friable and brown in color. Meanwhile, whitish friable callus were observed in the presence of $2.0 \mathrm{mg} / \mathrm{L}$ of 2,4-D and $2.5 \mathrm{mg} / \mathrm{L} \mathrm{BAP,} 2.0 \mathrm{mg} / \mathrm{L}$ of $2,4-\mathrm{D}$ and $1.5 \mathrm{mg} / \mathrm{L}$ BAP, $1.0 \mathrm{mg} / \mathrm{L}$ of $2,4-\mathrm{D}$ and 1.5 
$\mathrm{mg} / \mathrm{L}$ of BAP and $1.0 \mathrm{mg} / \mathrm{L}$ of $2,4-\mathrm{D}$ and $0.5 \mathrm{mg} / \mathrm{L}$ of BAP in combined treatment. They were all soft and smooth callus with wet looking surface.

The least amount of callus, 5\% was produced under the combined treatment of $5.0 \mathrm{mg} / \mathrm{L}$ of $2,4-\mathrm{D}$ and $1.5 \mathrm{mg} / \mathrm{L}$ of BAP, and $5.0 \mathrm{mg} / \mathrm{L}$ of $2,4-\mathrm{D}$ and $2.0 \mathrm{mg} / \mathrm{L}$ of BAP. All the leaf segments treated with the presence of $5.0 \mathrm{mg} / \mathrm{L}$ of 2,4-D in combination with BAP resulted in low level callus production. Table 1 indicated that the percentage of callus induction reduced as the concentration of 2,4-D increased. Effective callusing was observed in the presence of low level of 2,4-D and medium level of BAP.

\section{Conclusion}

Leaf explants treated with 2,4-D and BAP in combined exposure resulted in callus induction. The highest percentage of callus from leaf explants was produced on the medium containing $2.0 \mathrm{mg} / \mathrm{L}$ of $2,4-\mathrm{D}$ and $2.5 \mathrm{mg} / \mathrm{L}$ of BAP in combined exposure. In short, callus induction of $T$. paniculatum could serve as an alternative regeneration pathway for this important medicinal pant.

\section{References}

[1] C.N. Stewart, Plant Biotechnology and Genetics: Principles, Techniques and Applications. Hoboken, NJ: John Wiley \& Sons, Inc, 2012.

[2] M. Ikeuchi, K. Sugimoto \& A. Iwase, "Plant Callus: Mechanisms of Induction and Repression" Plant Cell, 25(9), 3159-3173, 2013 Retrieved http://www.ncbi.nlm.nih.gov/pmc/articles/PMC3809525/

[3] L. R. Berg, Introductory Botany: Plants, People, and Environment ( $2^{\text {nd }}$ ed.), 2007 Retrieved from http://www.amazon.com/IntroductoryBotany-Environment-Non-media-Edition/dp/049538478X

[4] C. C. Giri \& A. Giri, A, Practical Biotechnology: Pratical Manual, 2007. Retrieved from http://books.google.com.my/books?id=wmnFGjPFStwC\&pg=PA3\&s ource $=$ gbs_selected_pages $\&$ cad $=3 \# \mathrm{v}=$ onepage $\& \mathrm{q}=$ callus $\% 20$ inductio $\mathrm{n} \& \mathrm{f}=$ false

[5] W. J. Ho \& I. K. Vasil, "Somatic embryogenesis in sugarcane (Saccharum officinarum L.) I. The morphology and physiology of callus formation and the ontogeny of somatic embryo", Protoplasma, 118(3), 169-180, 1983. doi: 10.1007/BF01281800

[6] H. E. Street, "Plant Tissue and Cell Culture", Science, 184(4133), 151-152, 1977. doi: 10.1126/science.184.4133.151-a

[7] Nic \& Nath. Jewels of opar Talinum paniculatum, 2009. Retrieved from http://myfolia.com/plants/3921-jewels-of-opar-talinumpaniculatum

[8] C. Thanamool, A. Thaeomor, S. Chanlun, P. Papirom \& S. Kupittayanant, "Evaluating the anti-fertility activity of Talinum paniculatum (jacq.) gaertn in female wistar rats", African Journal of Pharmacy and Pharmacology, 7(26), 1802-1807, 2013. doi: 10.5897/AJPP2013.2974

[9] M. Mosango, Talinum paniculatum (Jacq.) Gaertn. Prota4U. 2004. Retrieved

fromhttp://www.prota4u.org/protav8.asp?fr=1\&p=Talinum+paniculat um+(Jacq.)+Gaertn.

[10] Rob's Plant, Talinum paniculatum, n.d. Retrieved from: http://www.robsplants.com/plants/TalinPanic

[11] T. Murashige \& F. Skoog, "A revised medium for rapaid growth and bioassays with tobacco tissue cultures", Physiologia Plantarum, 15:473-497.
About Author (s):

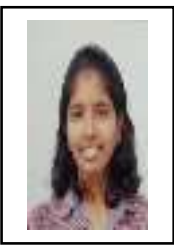

Prianangkai Karuppiah

Research Assistant

Research focus on plant tissue culture

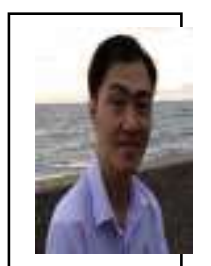

Weng Hing Thong

Senior Lecturer

Research focus on teaching and learning, plant biotechnology, effective microorganisms and mycology. 